\title{
Solitary Fibrous Tumor of the Omentum: Presentation of a Case and Literature Review
}

\author{
Carlo Biddau ${ }^{1}$, Lorenzo Cereser ${ }^{1}$, Panagiotis Paliogiannis ${ }^{2}$, Giovanni Terrosu $^{1}$, Alessandro Uzzau ${ }^{1}$
}

'Department of Medicine, University of Udine, Piazzale Kolbe, 33100 Udine, Italy 2Department of Medical, Surgical, and Experimental Sciences, University of Sassari Viale San Pietro 43, 07100, Sassari, Italy

\section{ABSTRACT}

Solitary fibrous tumor (SFT) and hemangiopericytoma (HPC) were considered, since their firsts description in the literature, as separate entities. The World Health Organization (WHO) classification of soft tissue tumors in 2013 declared the term HPC obsolete, and considered these lesions as features of the extrapleural SFT category. Herein we present a rare case of SFT originating from the great omentum. A 68 years old woman was admitted to our hospital with acute abdominal pain. Computed tomography revealed a 142 × 102 x $100 \mathrm{~mm}$ solid mass located in the pelvis, that simulated an adnexal lesion. An explorative laparotomy was performed, and a mass of the great omentum with a significant vascular pedicle arising from a branch of the left gastroepiploic artery was revealed. The tumor was completely resected. Microscopically it was composed by non-organized and spindle-shaped cells exhibiting atypical nuclei, arranged in short fascicles, and was diagnosed as. An extensive search was conducted in public scientific databases for published articles on the topic, with the aim to comprehensively describe the demographic, clinical, pathological and prognostic features of SFT; 60 previous cases have been identified and reviewed.

Key words: omentum, solitary fibrous tumor, hemangiopericytoma, mesenchymal tumor, SFT/HPC

\section{INTRODUCTION}

The greater omentum is an anterior vascular fatty apron-like fold supporting the abdominal viscera protecting them against tumors and infections. The most common malignancies of the greater omentum are due to carcinomatosis, secondary to peritoneal or hematogenous spread of digestive (colorectal, stomach, pancreas) or ovarian tumors. Solitary fibrous tumor (SFT) is a mesenchymal neoplasm that generally grows in the pleura, and occasionally in other body districts, including subcutaneous tissue, head and neck (especially the orbit), thoracic wall, mediastinum, pericardium, and retroperitoneum. Other reported locations include the meninges, spinal cord, periosteum, as well as organs like the salivary glands, lung, thyroid, liver, gastro-intestinal tract, adrenals, urinary bladder, prostate, spermatic cord and testes, and can be both benign and malignant (1). Only a few SFT cases involving the omentum have
Corresponding author:

Carlo Biddau, MD

Department of Medicine

University of Udine

Piazzale Kolbe, 33100 Udine, Italy

Phone: 00393927396249

E-mail: carlo.biddau@gmail.com

\section{Abbreviations:}

SFT - solitary fibrous tumor;

HPC - hemangiopericytoma;

CECT - contrast-enhanced computed tomography;

TKIs - tyrosin kinase inhibitors;

Received: 24.01.2020

Accepted: 10.03.2020

Copyright $\odot$ Celsius Publishing House www.sgo-iasgo.com 
been reported in the scientific literature to date. We herein report a rare case of omental SFT.

\section{CASE REPORT}

A 68 years old Caucasian woman, with no remarkable medical history, was referred to the University Hospital of Udine, Italy, for abdominal pain lasting 48 hours, with no further symptoms such as fever, stomach-ache, nausea or vomiting. Clinical examination showed a plethoric and soft abdomen, with no remarkable signs, but with a tender palpable mass moderately painful in the right lower abdominal quadrant. Laboratory data showed high white blood cell count $(13200 / \mu \mathrm{L})$ and C-reactive protein $(41 \mathrm{mg} / \mathrm{L})$. A contrast-enhanced computed tomography (CECT) scan of the abdomen and pelvis was performed, and showed a $142 \times 102 \times 100 \mathrm{~mm}$ mass occupying large part of the lower abdominal cavity, compressing the bladder and uterus, and resembling an adnexal lesion (figures 1 and 2). The mass showed low signal density, with regular and well defined borders, and after contrast injection, it was clearly enhanced, showing a mixed pattern of well vascularized and apparently necrotic areas. The mass drained into a dilated omental venous plexus. Neither vascular thrombosis, nor spread to adjacent organs were detected.

An explorative laparotomy was performed, and a large tumor originating from the greater omentum was found. The lesion, partly surrounded by omentum, was tightly adherent with the inferior curve of the stomach. A dilated artery apparently originating from the left gastroepiploic artery, which seemed to feed the tumor, and an abundant and expanded blood vessel network, were present along the surface of the mass, leading to a $100 \mathrm{ml}$ blood loss during excision. The lesion was successfully isolated and excised in toto with no technical difficulties and without resection of adjacent organs. The postoperative course of the patient was uneventful, and she was discharged five days after surgery. The patient gave her informed consent for all the medical procedures, and for the use of her anonymous clinical data for research purposes.

At gross pathological examination, the tumor measured $140 \times 95 \times 80 \mathrm{~mm}$ in size, and was wellcircumscribed, solid, multilobulated, beige-pink in colour, with a $55 \mathrm{~mm}$ haemorrhagic area (figure 3). Microscopically, it was composed of non-organized spindle-shaped cells, divided by branching vessels with intravascular thrombosis and multiple ischemic areas. No remarkable atypia was detected. Few mitotic figures $(<3 / 10$ high power field) were present. No immunohistochemical staining for EMA, CD99, cytokeratine, desmin, CD10, CD117 and DOG-1 was found, while staining positivity for CD34, bcl-2 and smooth muscle actin (SMA) was detected, leading to the diagnosis of a SFT. The patient was regularly followed-up with periodic imaging for the last four years, and no recurrences occurred.

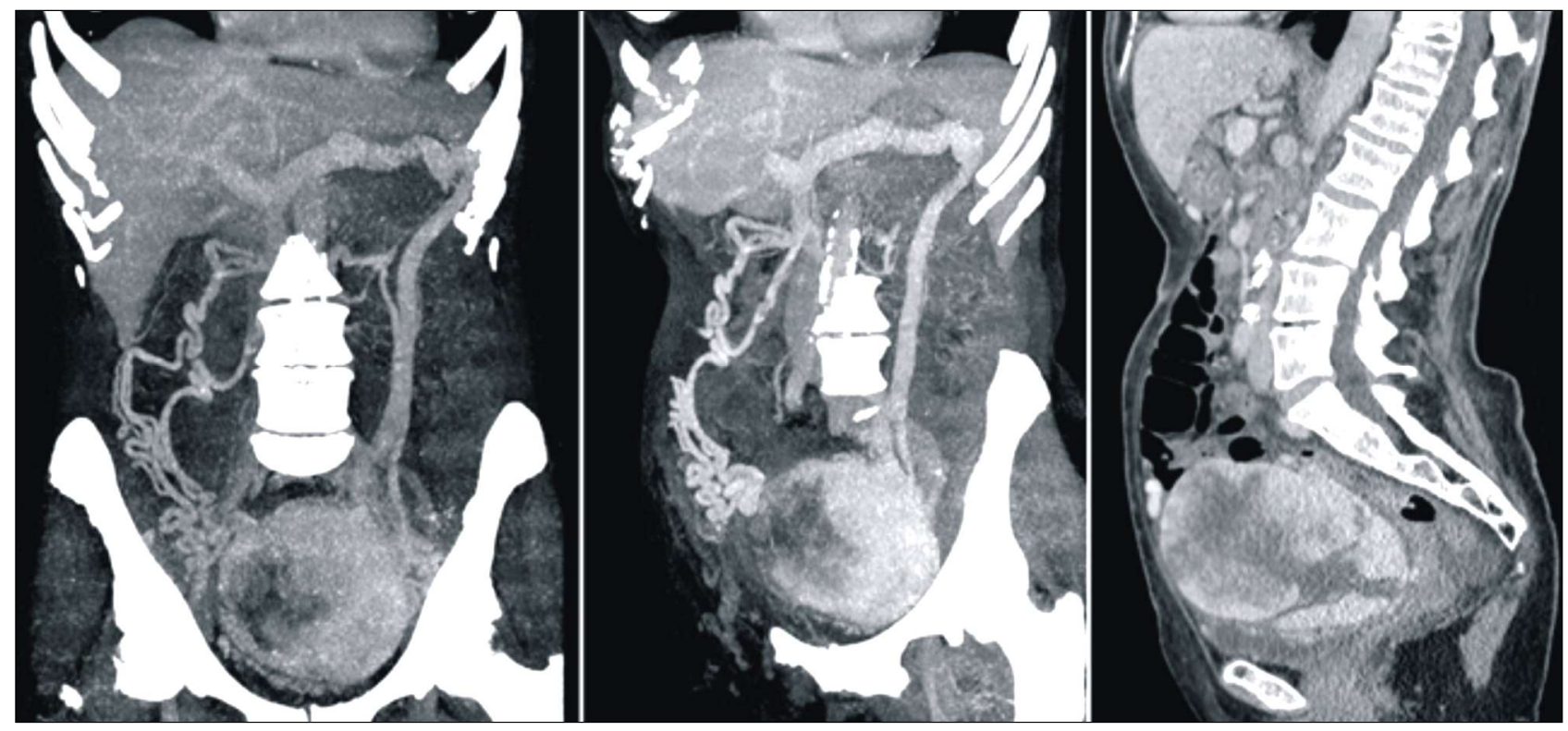

Figure 1 - Abdominal computed tomography scan showing the pelvic omental SFT 


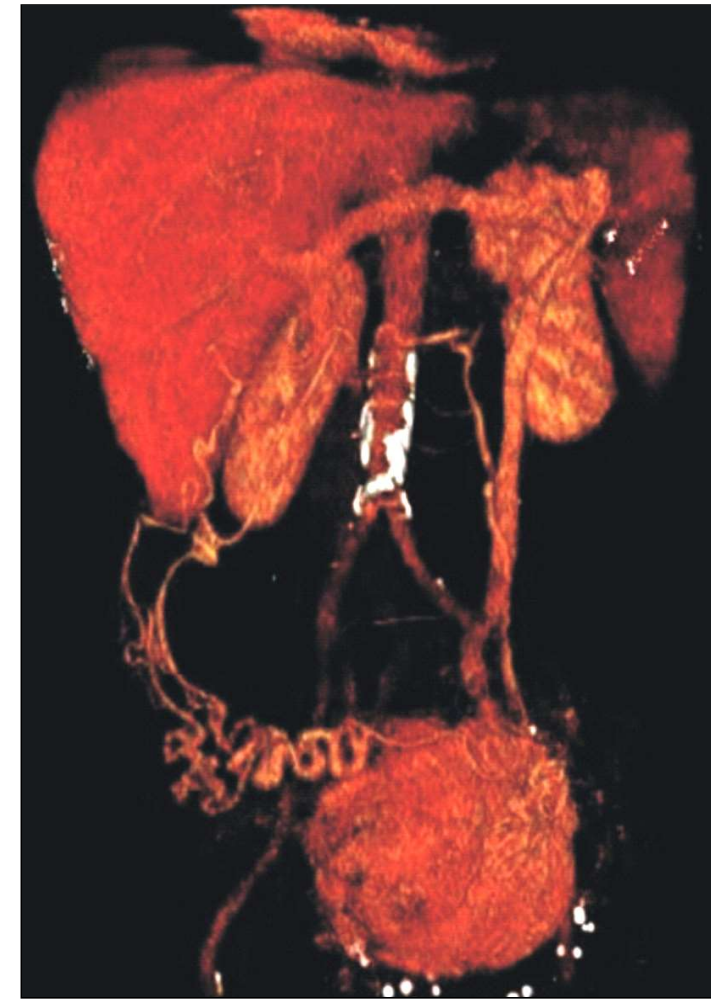

Figure 2 - Abdominal computed tomography scan showing a hypervascularized and heterogeneous solid tumor in the pelvis, with vascular feeding from the left gastroepiploic vessels

\section{DISCUSSION}

The first description of SFT dates back in 1931 (2) as a neoplasm originating from the pleura. The pleural sheets are most commonly affected by malignant mesothelioma, and represent the most common site of occurrence of SFT (3). It has been, indeed, hypothesized that SFT originates from sub-mesothelial mesenchymal cells (4). Extrapleural sites of origin, like the peritoneum, mediastinum, limbs, orbits and parotid glands have been subsequently described, and are less frequent but associated with particular clinico-pathological implications and higher risk of malignancy. Hemangiopericytoma (HPC), on the other hand, was first described by Stout and Murray in 1942 as a rare tumor of Zimmermann's pericytes (5). Although this tumor can arise anywhere, the muscles of the lower limbs, the pelvic fossa, and the retroperitoneum are the predominant sites of origin described. The fourth edition of the World Health Organization (WHO) Classification of Tumours of Soft Tissue and Bone published in February 2013 (6) erased these two entities, which are since then considered a unique tumor occurring commonly at all the sites of origin mentioned. Nevertheless, some pathologists continue

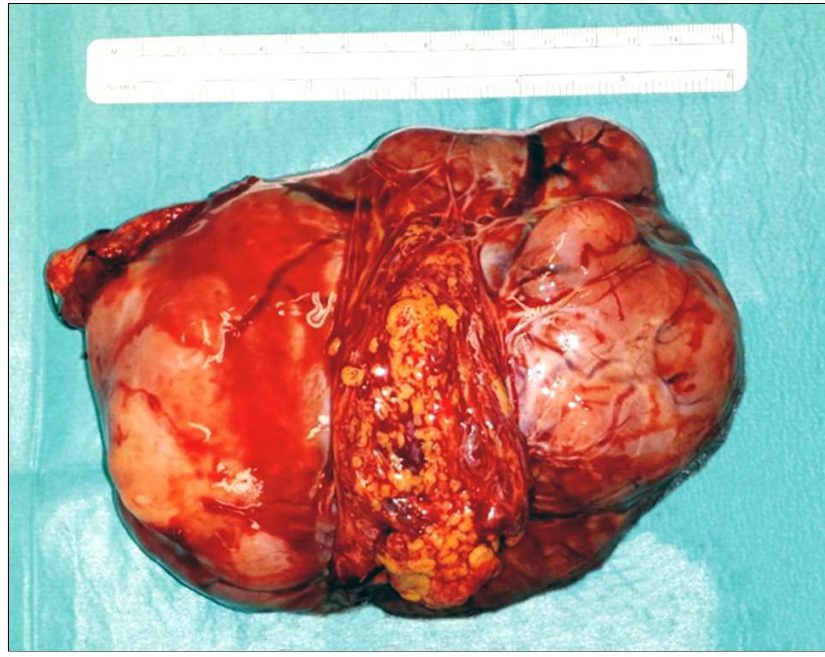

Figure 3 - Gross appearance of the resected SFT: a well-encapsulated pink and smooth solid mass, measuring approximately $14 \mathrm{~cm}$

to maintain the old classification, despite the morphological and pathological features of the lesions are indeed related.

To date, only a few cases of SFT have been reported. We conducted an extensive electronic article search on PubMed and Scopus databases with the aim to identify published reports on SFT. The following keywords were used for research: "solitary fibrous tumor", "solitary fibrous tumour", "hemangiopericytoma", "haemangiopericytoma", "great omentum", "greater omentum", "omentum" and "omental" both as single terms or in combination. All the results were screened by two researchers $(C B, A U)$, regardless of the reporting language, for cases with demographic, clinical and pathological information available. Subsequently, a cross-check of the reference lists of selected articles was performed to find any missed papers.

This way, there were 60 cases identified in 57 articles (7-63), a number consistently higher than those reported in previous reviews. The main demographic, clinical, pathological and immunohistochemical data of the cases enrolled are summarized in table 1. SFT did not show any gender predilection. Most cases occured during the 5th and 6th decades of life, and no environmental factors have been identified to increase the risk of SFT (64). The mean age in the whole cohort was 51 (range 24-92) years, and 29 patients were males $(51 \%$, table 1$)$. In five patients the age or gender were not mentioned.

Patients with intra-abdominal SFT most commonly had a relatively indolent behaviour, and were often affected by a palpable abdominal mass or abdominal pain, vomiting and weight loss (65). Information about 
the personal clinical history was available in 52 cases; abdominal-pelvic mass (21\%) and vomiting (7\%) only in $9(15 \%)$ cases the patients were totally were the clinical manifestations most frequently asymptomatic, while abdominal or pelvic pain (41\%), encountered (table 1). The clinical symptoms were

Table 1 - Main demographic, clinical and immunohistochemical findings of SFT of the greater omentum as depicted in the current literature

\begin{tabular}{|c|c|c|c|c|}
\hline Author (citation) & Year & Age/Gender & Symptoms/signs & IHC \\
\hline Stout et al. (7) AUTOPSY & 1943 & $92 / \mathrm{M}$ & abdominal mass & $N A$ \\
\hline Stout et al. (8) & 1963 & 63/M & abdominal mass with pain & NA \\
\hline Stout et al. (8) & 1963 & $57 / F$ & NA & $N A$ \\
\hline Stout et al. (8) & 1963 & $64 / \mathrm{M}$ & abdominal pain, nausea & $N A$ \\
\hline Lortat-Jacob et al. (9) & 1966 & NA/M & abdominal mass, constipation & $N A$ \\
\hline Goldberg et al. (10) & 1968 & $30 / F$ & abdomnial pain & NA \\
\hline Meyer et al. (11) & 1976 & $55 / \mathrm{M}$ & abdominal mass, constipation & Reticulin+ \\
\hline Krejczy et al. (12) & 1978 & NA/NA & $N A$ & $N A$ \\
\hline Alusik et al. (13) & 1978 & NA/NA & NA & NA \\
\hline Harder et al. (14) & 1983 & $37 / M$ & abdominal pain & NA \\
\hline Karabanov and Safiullin (15) & 1989 & $61 / F$ & abdominal mass & NA \\
\hline Imachi et al. (16) & 1990 & $62 / F$ & abdominal distension with pain & NA \\
\hline Schwartz et al. (17) & 1991 & $40 / \mathrm{M}$ & abdominal mass with pain, wheight loss & NA \\
\hline Cajano et al. (18) & 1995 & NA/NA & NA & NA \\
\hline Bertolotto et al. (19) & 1996 & $33 / F$ & No & NA \\
\hline Pozharliev et al. (20) & 1997 & $45 / \mathrm{M}$ & abdomnial pain, atshenia & NA \\
\hline Watanabe et al. (21) & 1998 & $66 / \mathrm{M}$ & No & CD34+ \\
\hline Borgmann et al. (22) & 1999 & $32 / F$ & abdominal mass & NA \\
\hline Borgmann et al. (22) & 1999 & $57 / F$ & abdominal mass & NA \\
\hline Rao et al. (23) & 2000 & $67 / M$ & abdominal lump & NA \\
\hline Kaneko et al. (24) & 2003 & $70 / F$ & lower abdominal mass grown over the past year & NA \\
\hline Bovino et al. (25) & 2003 & $46 / F$ & severe upper abdominal pain, nausea, vomiting & $\begin{array}{l}\text { vimentin+, keratin-, } \\
\text { LCA-, S100- }\end{array}$ \\
\hline Patriti et al. (26) & 2004 & 24/M & lower abdominal pain, diarrhea, fever & $\begin{array}{l}\text { CD34+, bcl-2+, } \\
\text { pancytokeratin- }\end{array}$ \\
\hline Ahmad et al. (27) & 2004 & $74 / F$ & $\begin{array}{l}\text { abdominal distension, weight loss, diarrhea, } \\
\text { vomiting }\end{array}$ & $\begin{array}{l}\text { CD34+, vimentin+, } \\
\text { SMA+, desmin+, Factor VIII+ } \\
\text { S100-, cytokeratin-, CEA- }\end{array}$ \\
\hline Crusco et al. (28) & 2005 & 28/M & acute pain in the lower left quadrant & NA \\
\hline Kim et al. (29) & 2005 & $60 / F$ & NA & NA \\
\hline Piazza et al. (30) & 2005 & $28 / \mathrm{F}$ & acute pelvic pain & NA \\
\hline Sukharev et al. (31) & 2006 & NA/NA & NA & NA \\
\hline Shiba et al. (32) & 2007 & $41 / F$ & epigastric pain & $\begin{array}{l}\text { CD34+, factor XIIla+, } \\
\text { HLA-DR+ }\end{array}$ \\
\hline Slupski et al. (33) & 2007 & $61 / \mathrm{M}$ & left lumbar pain & NA \\
\hline Salem et al. (34) & 2008 & $60 / \mathrm{M}$ & periumbilical pain, weight loss & $\begin{array}{l}\text { CD34+, CD99+, SMA-, } \\
\text { desmin-, S100-, C-kit - }\end{array}$ \\
\hline Chatterjee et al. (35) & 2008 & $41 / \mathrm{M}$ & NA & CD34+ \\
\hline Peixoto Callejo (36) & 2009 & $44 / \mathrm{M}$ & abdominal tumour, anorexia, weight loss & CD34+, CD117- \\
\hline Mosquera and Fletcher (37) & 2009 & 40/M & lower abdominal pain & $\begin{array}{l}\text { CD34+, p16+, p53+, EMA-, } \\
\text { AE1/AE3- }\end{array}$ \\
\hline Prakash et al. (38) & 2009 & $45 / F$ & lower abdominal pain & $N A$ \\
\hline Kucuk et al. (39) & 2009 & 70/M & abdominal diffuse pain, nause, vomiting & CD34+, vimentin+ \\
\hline
\end{tabular}


Table 1 - Main demographic, clinical and immunohistochemical findings of SFT of the greater omentum as depicted in the current literature (continuation)

\begin{tabular}{|c|c|c|c|c|}
\hline Author (citation) & Year & Age/Gender & Symptoms/signs & IHC \\
\hline Maassarani et al. (40) & 2010 & $63 / F$ & NA & NA \\
\hline Morris-Stiff et al. (41) & 2011 & 68/M & No & CD34+ \\
\hline Garbin et al. (42) & 2011 & $27 / F$ & No & NA \\
\hline Furukawa et al (43) (AUTOPSY) & 2012 & 69/M & NA & $\begin{array}{l}\text { CD34+, vimentin+, SMA+, } \\
\text { type IV collagen+, S-100-, } \\
\text { cytokeratin- }\end{array}$ \\
\hline Uemura et al. (44) & 2012 & $48 / \mathrm{M}$ & painless mass in the left inguinoscrotal area & $\begin{array}{l}\text { CD34+, CD99+, desmin-, } \\
\text { S100-, SMA-, bcl-2- }\end{array}$ \\
\hline Zong et al. (45) & 2012 & 29/M & $\begin{array}{l}\text { epigastric discomfort and compression, } \\
\text { weight loss }\end{array}$ & $\begin{array}{l}\text { CD34+, CD99-, bcl-2+, } \\
\text { SMA+, vimentin+, CD117-, } \\
\text { CD68-, cytokeratin-, } \\
\text { calretinin-, desmin-, EMA-, } \\
\text { F8-, S100- }\end{array}$ \\
\hline Virgilio et al. (46) & 2014 & $74 / \mathrm{M}$ & No & $\mathrm{CD} 34+, \mathrm{bcl}-2+$ \\
\hline Becker et al. (47) & 2014 & $41 / F$ & $\begin{array}{l}\text { distended abdomen, early satiety, } \\
\text { postprandial vomiting }\end{array}$ & $\begin{array}{l}\mathrm{CD} 34+, \text { bcl-2+, } \\
\text { vimentin+ }\end{array}$ \\
\hline Osawa et al. (48) & 2014 & $32 / F$ & irregular vaginal bleeding & $\begin{array}{l}\text { CD34+, bcl-2 +, SMA+, S-100-, } \\
\text { c-kit - }\end{array}$ \\
\hline Harada et al. (49) & 2014 & $62 / F$ & vaginal discharge & $\begin{array}{l}\text { CD34+, CD99+, bcl-2+, vimentin+, } \\
\text { p16+, p53+, CD10+, PR+, S100+, } \\
\text { c-kit+, EMA+, cytokeratin } \\
\text { AE1/AE3+, SMA-, desmin-, D2-40 -, } \\
\text { calretinin-, ER-, CD31- }\end{array}$ \\
\hline Sato et al. (50) & 2014 & $85 / F$ & hypogastric mass & NA \\
\hline Senda et al. (51) & 2014 & $45 / F$ & No & $\begin{array}{l}\text { CD34+, bcl-2+, c-kit+, } \\
\text { S-100-, desmin- }\end{array}$ \\
\hline Cazejust et al. (52) & 2015 & $68 / F$ & left subcostal pain & CD34+, bcl-2+, C-kit -, DOG1- \\
\hline Urabe et al. (53) & 2015 & $52 / \mathrm{M}$ & No & $\begin{array}{l}\text { CD34+, STAT6+, C-kit-, S100 -, } \\
\text { desmin -, 1A4- }\end{array}$ \\
\hline Moszynski et al. (54) & 2016 & $29 / F$ & pelvic pain, loss of appetite, bloating & CD34+ \\
\hline Jaber et al. (55) & 2016 & $69 / F$ & lower abdomen pain & $\begin{array}{l}\text { vimentin+, CD34+, CD31+, } \\
\text { reticulin+, keratin -, EMA- }\end{array}$ \\
\hline Archid et al. (56) & 2016 & 25/M & lower abdominal pain & $\begin{array}{l}\text { CD 34+, CD99+, AE1/3-, } \\
\text { desmin-, CD31-, CD117-, } \\
\text { D0G1 -, S100- MIB1 5\% }\end{array}$ \\
\hline Rodriguez Tarrega et al. (57) & 2016 & $34 / \mathrm{F}$ & No & $\begin{array}{l}\text { CD34+, CD99+, beta } \\
\text { catenin+, SMA-, desmin-, } \\
\text { kit-, D0G1- }\end{array}$ \\
\hline Michiura et al. (58) & 2016 & $36 / M$ & cough, abdominal mass & $\begin{array}{l}\text { CD34+, bcl-2+, CD99+, p53+, } \\
\text { S-100-, a-SMA-, c-kit-, desmin- }\end{array}$ \\
\hline Bushira S.S. (59) & 2017 & 45/M & abdominal pain and swelling & CD34+, factor-IIla+, HLA-DR+ \\
\hline Yousefi et al. (60) & 2018 & $24 / F$ & lower abdominal pain & $\begin{array}{l}\text { CD34+, CD99+, cytokeratin-, } \\
\text { LCA-, CD117-, Synaptophysine-, } \\
\text { Calretinine-, Inhibin- }\end{array}$ \\
\hline Vasdeki et al. (61) & 2018 & $72 / \mathrm{M}$ & recurrent mass of the anterior abdominal wall & CD34+, CD99+, vimentin+, \\
\hline Jung and Bae (62) & 2019 & $57 / \mathrm{M}$ & No & CD34+, STAT 6+ \\
\hline Suzuki et al. (63) & 2019 & $45 / F$ & abdominal pain & $\begin{array}{l}\text { CD34+, bcl-2+, STAT6+, } \\
\text { CD99+, c-kit-, S-100-, desmin- }\end{array}$ \\
\hline
\end{tabular}

EMA: epithelial membrane antigen; ER: estrogen receptor; F: female; HIC: immunohistochemistry HPC: hemangiopericytoma; LCA: leukocyte common antigen; M: male; NA: not available; PR: progesterone receptor; SFT: solitary fibrous tumor;

SMA: smooth muscle actin 
often attributable to a mass-compression effect on the surrounding anatomic structures. In addition, three cases manifested with haemoperitoneum $(26,28,39)$, while five lesions mimicked an ovarian tumor $(16,27,54,57,60)$.

The imaging techniques most frequently employed were roentgenograms and CECT. SFT tend to be welldefined, ovoid, and heterogeneously enhanced lesions in imaging. CECT and magnetic resonance imaging (MRI) appearance of abdominal and pelvic SFTs commonly consists in large, well-defined, ovoid, moderate enhancing masses, with heterogeneous CT attenuation or MRI signal intensity due to variable degrees of necrosis, haemorrhage and/or cystic evolution $(65,66)$. Such non-specific imaging features lead to a wide spectrum of differential diagnoses to consider, including mainly other highly vascularized and/or fibrous-rich tumours such as leiomyosarcoma, neurogenic tumour, lymphoma, malignant fibrous histocytoma and mesothelioma. (65). The presence of a prominent vascular pedicle, although non-specific, has been described as a useful diagnostic feature of SFTs, and has been reported in $35 \%$ to $100 \%$ of the cases (67).

Histologic features that define SFT as a malignant neoplasm have been proposed, but no unanimous criteria have been established. Zong et al. (45) suggested a risk assessment algorithm to predict SFT behaviour based on tumor size, mitotic activity, cellularity and pleomorphism. It distinguishes SFTs in very low, low, intermediate and high risk tumors. Furthermore, in a series of 110 cases, Demicco et al. proposed a risk stratification model for metastasis and death from disease, identifying three prognostic groups: low, intermediate and high risk patients (68). Nevertheless, no comprehensive studies have been performed to accurately determine the neoplastic aggressiveness of SFT so far. Furthermore, less is known about the genetic ad molecular events responsible for the pathogenesis of SFT, and how this may relate to clinically determined risk factors. In addition, the predicitve value of the few immunohistochemical or molecular biomarkers (including p53, telomerase activity, cycle expression, and Ki67) that have been suggested to have prognostic significance in SFT, remains yet to be clarified.

On gross pathologic examination, SFTs were commonly solid masses, well-circumscribed, encapsulated, and non-infiltrating. Most cases showed prominent vascularity with numerous small and medium size vessels, often adopting focally a hemangiopericytic growth pattern. Typical histological features of SFTs consist in a combination of hypercellular and collagenous areas; in some cases, it can be difficult to evaluate malignancy only according to morphology and immunohistochemical (IHC) features may be useful like positivity of CD34, bcl-2 and STAT6 which are the most important markers for diagnosis, especially in differentiating SFTs from gastrointestinal stromal tumors (GISTS) (53). In particular, STAT6 has recently emerged as a sensitive and specific marker, which identifies the NAB2-STAT6 fusion product (69). Occasionally, SFTs are positive for epithelial membrane antigen (EMA), smooth muscle actin (SMA), and negative for cytokeratin, S100, and desmin. In our review, positivity for vimentin was found in all the 9 cases reporting on IHC (table 1). CD34 and bcl-2 were the immunostainings most frequently used (30 and 11 cases, respectively); the former was positive in $100 \%$, and the latter in $91 \%$ of the examined cases (table 1). Frequent immunostaining for CD 99 was detected (90\%), as well as negativity for desmin (10 of the 11 reported cases) and smooth muscle actin (SMA).

The ideal therapy for malignant SFTs is uncertain, and the assessment of the most effective clinical management remains to be established. Information about the employed treatments and the prognosis was available in 57 cases. In all these cases surgery was the treatment of choice, with an associated complete omentectomy perfomed in nine $(16 \%)$ cases. Three cases required an extended resection, with the exeresis of bilateral adnexa (two cases), as well as uterus, appendix and perirectal metastases. Considering the favourable oncological outcomes of SFT, radiotherapy is generally not indicated when surgical excision has resulted in negative margins, and it is usually reserved in cases with incomplete resection or recurrence. Chemotherapy or targeted therapies with tyrosin kinase inhibitors (TKIs) may be recommended especially in unresectable cases, since half of these tumours is positive for CKIT TKIs (70). However, it is difficult to identify the most effective chemotherapy regimen for advanced SFTs on the basis of the current evidence. Cytotoxic doxorubicin based, gemcitabine based, and paclitaxel based schemes are used for patients with locally advanced, recurrent, or metastatic disease, but results have been variable, often with low response rates (71). Several novel targeted strategies, like temozolomide bevacizumab combination therapy, sunitinib, sorafenib and pazopanib have recently shown promising results (72), but further studies are needed to validate their routine use.

Also the prognosis of patients affected by omental 
SFT remains difficult to establish. In general, most of the patients with extrapleural disease show a benign clinical course after complete surgical resection. The overall median 5- and 10-year survival rates after surgical resection are $59 \%$ to $100 \%$ and $40 \%$ to $89 \%$, respectively (73). Nevertheless, some omental SFTs showed aggressive malignant behavior resulting in recurrence or metastasis, even many years after the surgical removal. Ten (18\%) patients presented distant metastases with a median time between the start of frontline treatment and first recurrence of 25 months (range 3-52). Globally, six (10\%) patients died because of the disease, three $(5 \%)$ were alive with disease, and thirty (53\%) were free of disease in the cases reviewed.

\section{CONCLUSIONS}

In conclusion, we came across a rare case of giant SFT originating from greater omentum. Imaging, especially $\mathrm{CT}$ or $\mathrm{MRI}$, are useful for the detection and anatomic evaluation of these tumors, but only surgery with subsequent pathological examination and immunohistochemical tests can provide a certain diagnosis of SFT. Surgery, with or without radiation and chemotherapy, should be considered for treatment on the basis of the dimensions and extension of the lesions, with a long-term follow-up in order to early detect local recurrences and distant metastases.

\section{Conflict of interest}

The authors declare that there are no conflicts of interest.

\section{Consent}

Written informed consent was obtained from the patient for publication of this case report and accompanying images. A copy of the written consent is available for review by the Editor-in-chief of tis journal on request.

\section{REFERENCES}

1. Briselli M, Mark EJ, Dickersin GR. Solitary fibrous tumors of the pleura: eight new cases and review of 360 cases in the literature. Cancer. 1981:47(11):2678-89.

2. Klemperer P. Rabin CB. Primary neoplasms of the pleura, Arch Pathol. 1931;11:385-412.

3. Budroni M, Cossu A, Paliogiannis P, Palmieri G, Attene F, Cesaraccio $\mathrm{R}$, et al. Epidemiology of malignant pleural mesothelioma in the province of Sassari (Sardinia, Italy). A population-based report. Ann Ital Chir. 2014;85(3):244-8.

4. Hu Y, Mahar TJ, Hicks DG, Raymond D, Jones C, Wandtke JC, et al Malignant solitary fibrous tumor: report of 3 cases with unusual features. Appl Immunohistochem Mol Morphol. 2009:17(5):451-7.

5. Stout AP, Murray MR. Hemangiopericytoma: A vascular tumor featuring zimmermann's pericytes. Ann Surg. 1942 (116):26-33.

6. Fletcher CDM, Bridge JA, Hogendoorn PCW, Mertens F, editors. WHO Classification of Tumours of Soft Tissue and Bone. Pathology and Genetics of Tumours of Soft Tissue and Bone. 4th ed. Lyon: IARC Press, 2013.

7. Stout AP, Cassel C. Hemangiopericytoma of the omentum. Surgery. 1943:13:578-81.

8. Stout AP, Hendry J, Purdie FJ. Primary solid tumors of the greater omentum. Cancer. 1963;16:231-43.

9. Lortat-Jacob JL, Clot JP, Goyer B. Hémangio-péricytome épiploique. Mem Acad Chir (Paris). 1966;92(14):371-5. (French).

10. Goldberger RE, Schein CJ. Hemangiopericytoma of the Omentum. Report of a case with a unique presentation and review of the literature. Am Surg. 1968;34(4):291-5.

11. Meyer Ch M, Starlinger G, Stoll A, Batzenschlager A. L'hemangiopericytome du grand epiploon. Lyon Chir. 1976;72(3):194-7. (French).

12. Krejczy K, Gniłka W, Gumański R. Haemangiopericytoma sieci wiekszej. Pol Przegl Chir. 1978;50(12):1067-68. (Polish).

13. Alusik S, Dusek J, Alusiková M. Hemangiopericytom omenta. Vnitr Lek., 1978;24(12):1190-3. (Czech).

14. Harder T, Koischwitz D, Engel C. Primary umors of the mesentery and greater omentum (Primäre Tumoren der Mesenterien und des Omentum majus). Rofo. 1983;139(3):274-80. (German)

15. Karabanov GN, Safiullin RV. Zlokachestvennaia angioperitsitoma bo'Ishogo sa'Inika. Vestn Khir Im I I Grek. 1989;143(7):69-70. (Russian).

16. Imachi M, Tsukamoto N, Tsukimori K, Funakoshi $\mathrm{K}$, Nakano $\mathrm{H}$, Shigematsu $\mathrm{T}$, et al. Hemangiopericytoma of the omentum presenting as an ovarian tumor. Gynecol Oncol. 1990;39(2):208-13.

17. Schwartz RW, Reames M, McGrath PC, Letton RW, Appleby G, Kenady DE. Primary solid neoplasm of the greater omentum. Surgery. 1991;109(4):543-9.

18. Cajano P, Heys SD, Eremin O. Haemangiopericytoma of the greater omentum. Eur J Surg Oncol. 1995;21(3):323-4.

19. Bertolotto M, Cittadini G Jr, Crespi G, Perrone C, Pastorino R. Hemangiopericytoma of the greater omentum: US and CT appearance. Eur Radiol. 1996;6(4):454-6.

20. Pozharliev T, Khristova Z, Stoichkova N, Milev A, Petrov S. Hemangiopericytoma of the omentum--a review of the literature and a case report (Khemangioperitsitom na omentuma--literaturen pregled S prinos na edin sluchaī). Khirurgiia (Sofiia). 1997;50(5): 45-8. (Bulgarian).

21. 渡邊敦之，児島完治，吉永浩明他：大網原発solitary fibrous tumorの 1 例. 臨放 1998;43:403-6. (Japanese).

22. Borgmann $U$, Heidenreich W. Das intraabdominelle Hamangioperizytom: Ein unerwarteter Befund bei der Laparotomie). Zentralbl Gynakol. 1999:121(3):153-5. (German).

23. Rao SR, Rao RS, Sampat MB. Hemangiopericytoma of greater omentum. Indian J Gastroenterol. 2000; 19(1):33-5.

24. Kaneko K, Shirai Y, Wakai T, Hasegawa G, Kaneko I, Hatakeyama K. Hemangiopericytoma arising in greater omentum: report of a case. Surg Today. 2003;33(9):722-4.

25. Bovino A, Basso L, Di Giacomo G, Codacci Pisanelli M, Basile U, et al. Haemangiopericytoma of greater omentum. A rare case of acute abdominal pain. J Exp Clin Cancer Res. 2003:22(4):649-50.

26. Patriti $A$, Rondelli $F$, Gullà N, Donini A. Laparoscopic treatment of a solitary fibrous tumor of the greater omentum presenting as spontaneous haemoperitoneum. Ann Ital Chir. 2006;77(4):351-3.

27. Ahmad GF, Athavale R, Hamid BN, Davies-Humphreys J. Pelvic malignant hemangiopericytoma mimicking an ovarian neoplasm; a case report. J Reprod Med. 2004;49(5):404-7.

28. Crusco F, Chiodi M, Pugliese F, Mosca S, Fischer MJ, Lupattelli L. Benign omental hemangiopericytoma presenting with hemoperitoneum: radiologic findings. AJR Am J Roentgenol. 2005;184(3 Suppl):S67-9.

29. Kim BW, Wang HJ, Jeong IH, Ahn SI, Kim MW. Metastatic liver cancer: A rare case. World J Gastroenterol. 2005;11(27):4281-4.

30. Piazza L, Ferrara F, Pulvirenti A. Hemangiopericytoma of the greater omentum. Videolaparoscopic treatment: case report and review of the literature. Suppl Tumori. 2005;4(3):S128 
31. Sukharev VF, Novozhilov VN, Bakhtybaev DO, Dolidze UR Hemangiopericytoma of the greater omentum. Vestn Khir Im I I Grek. 2006;165(3):79.

32. Shiba H, Misawa T, Kobayashi S, Yokota T, Son K, Yanaga K Hemangiopericytoma of the greater omentum. J Gastrointest Surg. 2007;11(4):549-51.

33. Slupski M, Piotrowiak I, Wlodarczyk Z. Local recurrence and distant metastases 18 years after resection of the greater omentum hemangiopericytoma. World J Surg Oncol. 2007;5:63.

34. Salem AM, Bateson PB, Madden MM. Large solitary fibrous tumor arising from the omentum. Saudi Med J. 2008;29(4):617-8.

35. Chatterjee D, Sarkar P, Sengupta N, Singh WG. Hemangiopericytoma of Greater Omentum Presenting as a Huge Abdominal Lump. Saudi J Gastroenterol. 2008;14(2):88-9.

36. Peixoto Callejo I. Peritoneal solitary fibrous tumour (SFT): Iong-term survival of recurrent and metastasised SFT treated with cytoreductive surgery and intraperitoneal chemotherapy. Clin TransI Oncol. 2009;11(4):250-2.

37. Mosquera JM, Fletcher CD. Expanding the spectrum of malignant progression in solitary fibrous tumors: a study of 8 cases with a discrete anaplastic component--is this dedifferentiated SFT? Am J Surg Pathol. 2009;33(9):1314-21.

38. Prakash M, Mumtaz HA, Sodhi KS, Kapoor R, Khandelwal N. Hemangiopericytoma: an unusual cause of peritoneal carcinomatosis. Cancer Imaging. 2009:15:9:32-4.

39. Küçük HF, Gülmez S, Kaptanoğlu L, Akyol H, Kurt N, Yavuzer D. Acute abdomen due to rupture of hemangiopericytoma of the greater omentum: case report. Ulus Travma Acil Cerrahi Derg. 2009;15(6):611-3.

40. Maassarani F, Leroy C, Dekeuleneer R. Synchronous abdominal and thoracic solitary fibrous tumor: a case report. Acta Chir Belg 2010 110:225-7.

41. Morris-Stiff G, Falk GA, Joyce D, Rubin B, Chalikonda S. Primary omental haemangiopericytoma. BMJ Case Rep. 2011;2011.

42. Garbin 0 , Hummel M, Diana M, Wattiez A. Solitary fibrous tumor of the great omentum. J Minim Invasive Gynecol. 2011;18(6):694-5.

43. Furukawa S, Wingenfeld L, Takaya A, Nakagawa T, Sakaguch I, Morita S, Yamasaki S, Nishi K. Hemangiopericytoma with immunohistochemical examination: An autopsy case. Rom J Leg Med. 2012; 20:191-4.

44. Uemura K, Hayashi T, Matsuoka K. Solitary fibrous tumor of the greater omentum in an inguinal hernia sac. International Cancer Conference Journal 2012; 1(2):70-7.

45. Zong L, Chen P, Wang GY, Zhu QS. Giant solitary fibrous tumor arising from greater omentum. World J Gastroenterol. 2012;18(44): 6515-20.

46. Virgilio E, Antonelli MS, Bocchetti T, Balducci G. RE: Hemangiopericytoma of the Greater Omentum: A Potential Imaging Pitfall and Cause of Repeatedly Unsuccessful Angiographic Embolization Korean J Radiol. 2014;15(4):538-9.

47. Becker JHR, Koto MZ, Matsevych OY, Bida NM. Haemangiopericytoma/solitary fibrous tumour of the greater omentum. S Afr $J$ Surg. 2014;52(4):111-3

48. Osawa H, Nishimura J, Inoue A, Ueda M, Mokutani Y, Miyo M, et al. A case of solitary fibrous tumor from the greater omentum resected via laparoscopic surgery. Gan To Kagaku Ryoho. 2014;41(12): 2493-5.

49. Harada N, Nobuhara I, Haruta N, Higashiura Y, Watanabe H, Ohno S. Concurrent Malignant Solitary Fibrous Tumor Arising from the Omentum and Grade 3 Endometrial Endometrioid Adenocarcinoma of the Uterus with p53 Immunoreactivity. Case Rep Obstet Gynecol. 2014;2014:216340.

50. Sato T, Yamaguchi S, Koyama I, Okada Y, Kato Y. Acute lifethreatening portal venous dilatation induced by a huge solitary fibrous tumor of the omentum. Hepatogastroenterology. 2014; 61(136) 2200-2.

51. Senda $\mathrm{T}$, Ishikawa $\mathrm{H}, \mathrm{Omoto} \mathrm{H}$, Nitta $\mathrm{H}$, Itou $\mathrm{H}$, Kaneko K, et al. A Case of a Solitary Fibrous Tumor of the Greater Omentum. 2014;75 (7):2032-6

52. Cazejust J, Wendum D, Bourrier A, Chafai N, Menu Y. Solitary fibrous tumor of the greter omentum. Diagn Interv Imaging. 2015; 96(9):95961.
53. Urabe M, Yamagata Y, Aikou S, Mori K, Yamashita H, Nomura S, et al Solitary fibrous tumor of the greater omentum, mimicking gastrointestinal stromal tumor of the small intestine: a case report. Int. Surg. 2015;100:836-40.

54. Moszynski R, Szubert S, Tomczak D, Saad A, Samulak D, Sajdak S, et al. Solitary fibrous mass of the omentum mimicking an ovarian tumor: case report. Eur J Gynaecol Oncol. 2016;37(1):144-7.

55. Jaber S, Winer I, Rasool N. Recurrent Omental Hemangiopericytoma: A Therapeutic Challenge. Case Rep Obstet Gynecol. 2016;2016:2075157.

56. Archid R, Schneider CC, Adam P, Othman A, Zieker D, Königsrainer A. Hemangiopericytoma/solitary fibrous tumor of the greater omentum: a case report and review of the literature. Int J Surg Case Rep 2016;23:160-2.

57. Rodriguez Tarrega E, Hidalgo Mora JJ, Paya Amate V, Vega Oomen 0. Solitary fibrous tumor of the greater omentum mimicking an ovarian tumor in a young woman. Gynecol Oncol Rep. 2016;17:16-9.

58. Michiura T, Yamabe K, Hayashi N, Miyazaki Y, Sugimoto S, Kojima K, et al. A Surgical Case of Solitary Fibrous Tumor Originating from the Greater Omentum. Gan To Kagaku Ryoho. 2016;43(12):2265-7. (Japanese)

59. Bushira S. Hemangiopericytoma of the Greater Omentum with Pelvic Metastasis: A very rare occurrence. J Gastrointest Dig Syst. 2017;7:486.

60. Yousefi Z, Seresh L, Jafarian A, Shirinzadeh L, Babapour N, Nourkhomami S. Solitary Fibrous Tumor of the Greater Omentum Mimicking an Ovarian Tumor: A Case Report. Acta Sci Cancer Biol. 2018;2(3):14-6.

61. Vasdeki D, Bompou E, Diamantis A, Anagnostou A, Tepetes K, Efthimiou M. Haemangiopericytoma of the greater omentum: a rare tumour requiring long-term follow-up. J Surg Case Rep. 2018; 2018(5):rjy087.

62. Jung C-Y, Bae J-M. Primary omental malignant solitary fibrous tumour, an extremely rare malignancy: A case report and review of the literature. Arab J Gastroenterol. 2019;20(2):114-6.

63. Suzuki, Y, Hiramatsu, K, Amemiya, T, Seki, T, Arai T. A case of solitary fibrous tumor from the greater omentum presenting with severe abdominal pain caused by torsion. Jpn J Gastroenterol Surg. 2019;52(5):263-71. (Japanese).

64. Davanzo B, Emerson RE, Lisy M, Koniaris LG, Kays JK. Solitary fibrous tumor. Transl Gastroenterol Hepatol. 2018; 3: 94.

65. Li XM, Reng J, Zhou P, Cao Y, Cheng Z7, Xiao Y, Xu GH. Solitary fibrous tumors in abdomen and pelvis: Imaging characteristics and radiologic-pathologic correlation. World J Gastroenterol. 2014; 20(17):5066-73

66. Ginat DT, Bokhari A, Bhatt A, Dogra V, Imaging features of solitary fibrous tumors. AJR Am J Roentgenol. 2011;196(3):487-495.

67. Garcia-Bennett J, Olivé CS, Rivas A, Domínguez-Oronoz R, Huguet P. Soft tissue solitary fibrous tumor. Imaging findings in a series of nine cases. Skeletal Radiol. 2012;41(11):1427-33.

68. Olson NJ, Linos K1. Dedifferentiated Solitary Fibrous Tumor: A Concise Review. Arch Pathol Lab Med. 2018;142(6):761-6.

69. Demicco EG, Park MS, Araujo DM, Fox PS, Bassett RL, Pollock RE, et al. Solitary fibrous tumor: a clinopathological study of 110 cases and proposed risk assesment model. Mod Pathol. 2012;25(9): $1298-306$

70. Stacchiotti S, Negri T, Palassini E, Conca E, Gronchi A, Morosi C, et al. Sunitinib malate and figitumumab in solitary fibrous tumor: patterns and molecular bases of tumor response. Mol Cancer Ther. 2010;9(5):1286-97.

71. Park MS, Ravi V, Conley A, Patel SR, Trent JC, Lev DC, et al. The role of chemotherapy in advanced solitary fibrous tumors: a retrospective analysis. Clin Sarcoma Res. 2013;3(1):7.

72. Adachi M, Motohashi M, Kaku Y, Sugie S, Muramatsu Y, Sumitomo S. Management consideration for patient with a large solitary fibrous tumor occupying the infratemporal fossa: A case report. Mol Clin Oncol. 2018;8(4):549-2.

73. Kayani B, Sharma A, Sewell MD, et al. A review of the surgical management of extrathoracic solitary fibrous tumors. Am J Clin Oncol 2018:41:687-94. 